\title{
The Role of Civic Education In Developing The Moral Through Democracy Learning
}

\author{
Ani Sulianti' ${ }^{1)}$,Samsul Arifin ${ }^{2)}$, Halimatus Sakdiyah ${ }^{3)}$ \\ Faculty of Teacher Training and Education Panca Marga University of Probolinggo, Indonesia ${ }^{1,2,3)}$ \\ anisulianti@gmail.com ${ }^{1)}$, samsulariefnext@gmail.com ${ }^{2}$, halimatus99didi@gmail.com ${ }^{3)}$
}

\begin{abstract}
This study aimed to understand1) The role of Civic Education in developing the students' moral, 2) The application of Democracy learning in developing the students' moral. The research methods used in this study was a qualitative method. The technique of collecting data used observation and interview. The technique of data processing using triangulation. The technique of the data analysis used data reduction, data display, and data conclusion drawing verification. The result of this study showed that 1) Civic Education is very influential in developing the students' moral to interact with school and community or social environment 2) Democracy play an important role in developing their behaviour in social, tolerant, appreciate and respect each other.
\end{abstract}

Keywords: Civic Education, Moral, and Democracy.

\begin{abstract}
Abstrak. Penelitian ini bertujuan untuk mengetahui: 1). Peran pendidikan kewarganegaraan dalam mengembangkan moral peserta didik, 2). Penerapan pembelajaran demokrasi dalam mengembangkan moral peserta didik. Metode penelitian yang digunakan yaitu metode kualitatif. Teknik pengumpulan data menggunakan observasi dan wawancara. Teknik pengolahan data menggunakan triangulasi. Teknik analisis data menggunakan data reduction, data display, and data conclusion drawing verification. Hasil penelitian menunjukkan bahwa 1). Pendidikan kewarganegaraan sangatlah berpengaruh dalam mengembangkan moral peserta didik dalam berinteraksi dengan lingkungan sekolah dan masyarakat 2). Demokrasi berperan penting dalam mengembangkan perilaku peserta didik dalam bersosial, bertoleransi, saling menghargai dan menghormati.
\end{abstract}

Kata Kunci: Pendidikan Kewarganegaraan, Moral, Demokrasi. 


\section{INTRODUCTION}

Basically, education is held as a human effort to grow and develop the potentials of both physical and spiritual traits in accordance with the values that exist in society, and can prepare human resources or students who has moral and quality and can bring students towards the maturity, independence and responsibility, shameless, honest, polite, noble character, noble character so that they do not rely on their family, community or nation and country anymore.

As it has been stated by Kardiyat Wiharyanto (2014: 9) Education is a conscious and planned effort to create learning atmosphere and process so that students actively develop their potential to have religious-spiritual strength, self-control, personality, intelligence, noble character, as well as the skills needed by himself, society, nation and state.

Education is a process in increasing the ability to think in order to become an experience to apply what has been obtained when learning takes place both formally and informally (knowledge) in actions and behaviour in the community. Thus, the moral development of students is needed for the growth of good behaviour. The students' moral development is taught not only at the transfer of knowledge to students, but also how the students can appreciate and utilize the knowledge that has been obtained in their actions and behaviour in the community, so the result can be seen at the learning process and its applying in their life.

Civic education is very important to shape the students' moral in the school so that students are able to have a competent life provision, a high sense of nationalism and a self-defence in avoiding negative things that might occur in their life journey.

The students' moral development has many obstacles in implementing it to students since the moral development of students is only developed in civic education subject that has a great responsibility for the students' moral development.

Kardiyat Wiharyanto (2014: 10) Civic Education brings the students to become scientists and professionals who have a sense of nationalism and love for the country, democratic, and become citizens who have competitiveness; disciplined, actively participate in building a peaceful life based on the Pancasila value system. In addition, civic education can foster good moral values for students, so that they are independent, able to sort out, which are positive and negative.

The moral is a term that shows the application of the values of goodness in the form of action or behaviour. Although the term moral can indicate that morals are good or bad, but in applying, people are said to be moral if they apply the values of goodness in their behaviour.

In essence, moral behaviour is related to human dignity itself as the noblest creature on 
earth. In social life, behaving in accordance with good values or positive morals is needed to be used as a guide in the formulation of rules that govern life.

Moral resulted from intellectual behaviour, emotions, or thinking results of every human being which essentially it is a rule in life to respect and able to distinguish between right and wrong prevailing in a society. When people talk about one's morals, what is discussed is the habits, behaviour or actions of people or groups of people. As expressed by Nurul Zuriah (2011: 19) moral is an effort to develop a person's behaviour patterns in accordance with the will of the community.

The moral is a very important rule that applied to the school environment, as it can be a sign in social life so that the students can become good citizens with the spirit of Pancasila and high democracy later.

Morality has several indicators, especially indicators relating to the morality of students including the morality of students in association in school, family, and community, the morality of students about school discipline, student relations, and teachers, moral responsibility. Moral values and character are having a very tight relationship in manner.

Moral itself which has been raised by Dian Ibung (2009: 3) Moral is a belief about right, wrong, good and bad, in accordance with social agreements, which underlies action and thought. Democracy is considered as the first pillar to guarantee the brotherhood of human rights regardless of gender, age, skin colour, religion and nation. In education, these values are inculcated by looking at the differences between one another. Both the relationship among fellow students or between students and teachers who appreciate and respect each other (Fuad ikhsan 2005: 163)

In the learning process, the students are not only active, but they are also given the opportunity to determine the learning activities that they will do, along with civic education subjects' teachers.

The role of civic education through democracy learning that students can learn to think well through democracy learning that is applied by teachers. To support the students' future in the community. The term of democracy as in political literature is taken from ancient Greek, which it consists of two words, namely demos which means people and kratos which means power, and when it combined means power in the hands of people (Dede Rosyada 2013: 15)

Civic Education in providing students with an understanding of values and morals is still not optimal. This can be seen from the students' daily attitudes and behaviour. The behaviour of learners, among others, lack of respect for teachers, low adherence to school discipline. Therefore, certain efforts need to be made so that teachers are able to provide 
students with an understanding of values and morals in each learning.

Civic education through democracy learning is expected that students can develop moral so that the goals of civic education can be achieved, and establish the students who have good morals.

Civic education learning teaches the students to behave in accordance with the existing rules both within the school environment and in the community. Thus, civic education through democracy learning provides a space for students to continue to develop the morals contained in students' selfpotential.

The moral is very necessary for the students' development since it gives a very big influence on students. However, in the moral development of students that occur in the current era is very inappropriate for emulated. Because in the current era, the students' moral cannot be controlled by just giving a reprimand.

The burden of civic education that must be done in learning is very large. It is related to morals and the final value generated in the learning process. In addition, besides it teaches the insight of the archipelago, civic education also develops moral education in which it is not far from the values of Pancasila.

Civic education is one of the subjects that contains moral education so that, the students' moral development can be seen from the final results from the implementation of civic education towards the students to be able in developing the students' moral values in accordance with the values of Pancasila.

Through moral cultivation to students that is carried out by civic education, subjects are expected to be able to become students who have behaviours that are in accordance with the standards set by their social groups. Since the loss of moral values in students can lead to problems, that will be widely violated by students, so that expectations that in beginning became a guide in education will not be able to run properly. Thus, the moral development of students cannot be in accordance with the expectations and values of Pancasila.

The phenomenon that often arises in the community is the large number of students who are less aware of the behaviour that sometimes the behaviour is far from the morals desired in civic education in accordance with the values of Pancasila. For example, violations that are often committed by students are saying sentences that should not be spoken for parents or teachers of students in the school or the students' environment.

The problem of education in Indonesia is very complex, from teaching and learning activities, learning facilities and infrastructure to a morality gap between ideal conditions and theory that makes learning activities not run well. 


\section{RESEARCH METHODS}

The type of research used in this study was descriptive with a qualitative approach. Qualitative research is a research process (Qualitative research) is a study aimed at describing and analyzing phenomena of events, social activists, attitudes, beliefs, perceptions, people thoughts, individually or in groups. (Muliawan for 2014: 66). This research was carried out at SMK Raudlatul Jannah Probolinggo which it was located in Jatiadi village, Gending sub-district, East Java. The techniques of collecting data used were through observation and interviews. The technique of data analysis used in this study was an inductive data analysis technique, which was drawing conclusions from specific facts, then generalizing conclusions. The steps of data analysis in this study were data reduction, data categorization and unitization, data display, and making a conclusion.

\section{DISCUSSION}

Based on the results and discussion of research obtained in relation to the role of civic education in developing morals through learning democracy, as follows.

\section{The Role of Civic Education in Developing}

\section{the Students' Moral}

Raudlatul Jannah Vocational School always prioritizes moral values compared to the knowledge gained. They will feel that they will fail to score the next generation if the moral is not getting better every day, especially when viewed from the percentage of graduation many students do not have good morals and manners, so it is not in accordance with the basic of the state namely Pancasila.

In the current era of globalization, students tend to behave negatively like students with their peers do not respect each other, lack of tolerance, anarchism and students' act that can endanger others. Therefore, civic education can improve the morale of good students who are virtuous, disciplined in society, nation and state, morality, and have faith and devotion to the almighty God.

The important role of civic education in developing the students' moral as a vehicle in the moral learning of citizens both in the level of education and in behaving as an Indonesian citizen who can demonstrate the moral attitude of citizens in accordance with Pancasila.

Civic education in building the students' moral needs the support of openness of students as the young generation of the nation to be able to accept and care for the nation itself, practical and strategic needs include the needs of all levels of society or citizens in developing morals. Civic education is 
education that is compulsory for all levels of education from elementary to tertiary level.

The role of civic education in developing the students' moral to print the golden generation of the future of the Indonesian nation, is determined by how civic education can run in accordance with the objectives of civic education itself, so that civic education holds firmly on the moral development of learners through learning in class that can be implemented in the students' life both within in the school and community.

Civic education is a spearhead for the development of students' moral since in civic education there are values, norms and morals that can be gained by students. The moral development of students can be seen from the behaviour of students when at school, thus the benchmarks for the success of students to develop morals that is contained in the behaviour or moral of students that can be observed at the school environment.

The cultivation of moral values is not only monopolized by civic education subjects, it means that every subject can insert moral values into students. However, some people already consider that educating students to have good morality is one of the responsibilities that must be carried out by civic education subject. Therefore, a great responsibility is borne by civic education subject, appropriate steps or strategies need to be taken to develop morally in civic education learning.
The results of this study can be illustrated that students at the Raudlatul Jannah Vocational School had played an important role to educate and produce a generation of people with the spirit of Pancasila, namely by instilling good morals to students through civic education through democracy learning. The students here not only know about the subject matter of civic, but they played an active role in becoming good citizens by developing good moral values such as honesty in speaking, discipline, attention and care for others that the teacher has applied to students.

In fact, to be able to survive, be accepted by society and continue to develop as a good person, are not from one's material but from one's own personality, and to the ability to respect others, take responsibility for their actions and other aspects of others. The students' academic intelligence is not the main thing that is applied but from the attitude and behaviour.

The assessment of the students' moral can be seen through behaviour that shows the success of civic education in developing and instilling morale of students to have a nationalist and Pancasila spirit, which can be accepted in the wider community.

Moral can also be interpreted as good moral behaviour or ethical behaviour and in accordance with the rules that exist in education or society that can lead to a good personality. As stated by Zuriah nurul, (2011: 19) moral education is the students' personal 
development about the patterns of belief contained in the belief system of society about good things to do and bad things to avoid. Students can be said to be successful and accepted in the community is when students are able to adjust to the demands of their environment, by prioritizing the behaviour of their personalities.

Civic education can improve the good moral of students who are virtuous, disciplined in the community, nation and state, morality, and faith and devotion to an almighty God. As stated by A. baidillah and Abdul Rozak (2014: 6) civic education basically is to make Indonesian citizens who are intelligent, dignified and active in the life of the nation and state.

Civic education, besides plays an important role as a vehicle for the moral development of students, it is also as a place to make students as scientists and professionals in their scientific fields, as Kardiyat Wiharyanto (2014: 10) states that Civic Education is bringing students to be a scientist and professional who has a sense of nationality and love for the country, democratic; and become citizens who have foreign power; disciplined, actively participates in building a peaceful life based on the Pancasila value system.

Civic education also has a great responsibility for the moral development of students, so that the main role of civic education should be given more extra hours, thus the role of civic education can be seen maximally in terms of students' behaviour that shows the success of civic education in developing the students' moral.

\section{The Applying of Democracy Learning in Developing the Students' Moral}

Democracy education is realized in schools or democracy learning. Democratic schools are characterized by the involvement of stakeholders (teachers, students, school leaders, staff, and parents of students or the community) in matters relating to school discipline, so as to create moral development of students in accordance with the values Pancasila.

The teaching and learning process of students were often still not optimal in working with friends, they were also still minimal in respecting differences of opinion, and they were still lacking in understanding diversity in the school environment and in the community. This had a negative impact on teachers and students, which would result in gaps in the learning process. This democracy provided a positive picture where students can learn to think and tolerate well, which later can blend well with the community.

The term democracy was from the ancient Greek word. It consists of two words, namely demos which means people and kratos which means power, and when combined means power in the hands of people, Mustafa, Kamal Pasha (2002: 81). 
Civic education through the learning model of democracy in schools for students had a positive impact on the moral development of students, as in a learning model that used a democratic system, the students learn about responsibility, love for the nation and the state or love the motherland, having the soul of Pancasila, and so forth.

If we see from the understanding of democracy itself that is from the people, by the people and for the people, then democracy learning provides a learning experience that is different from the others, namely students are required to learn independently and solve a problem that exists in society, so that the learning experience obtained can measure the moral development that exists in students.

In connecting with that, as stated by Fuad ikhsan (2005: 163) Both the relationship between fellow students or between students and their teachers who respect and respect each other. Students are given the opportunity to provide responses, opinions and assessments of the values found. Democracy is used to instil values including openness, honesty, appreciation of other people's opinions, sportsmanship, humility, and tolerance through democratic students being invited to dare to express ideas, or opinions.

Democracy learning through civic education had a positive impact on students as they are taught for openness, honesty, respect for the opinions of others, sportsmanship, humility and tolerance so that, to develop moral attitudes of students can be developed through democracy learning through civic education.

Fuad ikhsan (2005: 163) Both the relationship between fellow students or the relationship between students and teachers who respect and respect each other. Democracy is considered the most important pillar to support the success of students in the learning process. Where students are trained to promote social sense, high tolerance, mutual respect, respect for teachers and togetherness.

The applying of democracy learning in the classroom had a positive impact so that developing the moral of students went well. Thus, the values that must be instilled in students such as openness, honesty, appreciation of other people's opinions and sportsmanship, which should be owned by students can, in fact, be absorbed and implemented by students in daily life.

Democracy is a way for humans to regulate and maintain the existence of their humanistic sovereignty in a very broad social spectrum. Humanistic existence is a basic human trait to survive, be recognized and contribute to their social environment, Syahputa Siswandi (2013: 1)

The applying of democracy learning through civic education in developing the students' moral provided new experiences for students to learn about the value of openness, honesty, respect for the opinions of others and sportsmanship which is highly valued. Civic 
education indeed is to make Indonesian citizens who are intelligent, dignified, active and moral in accordance with the values of Pancasila.

The great responsibility for civic education subjects through the learning model of democracy in developing the students' moral whose final results would be seen by applying students' moral values that lead to positive things that were in accordance with the principles of Pancasila as the basis of the nation-state Indonesia.

The applying of democratic learning provided a different experience which was to provide freedom for students to express themselves by providing opportunities to develop the students' moral well, since the students' moral was not only learned with theories that were given continuously but must be able to live and apply moral education that has been obtained properly, both informal and non formal education.

The development of the students' moral must be supported both in the school environment and community so that it can create good moral for students. Democracy learning to students in order to develop the students' moral well can be applied by students by showing good behaviour in the school environment and community, so learning using the democracy learning model can be said to be successful as it allows the students to behave in accordance with the values moral values that apply, both in the school environment and community.

\section{CONCLUSION}

Civic education in developing the students' moral was very influential. The students could play an active role to become good citizens by developing good moral values such as honesty in speaking, discipline, attention and care for others. Students were able to adjust to the demands of their environment, by prioritizing the behaviour of their personality. Democracy learning in the school environment was very helpful to support the success of students in the learning process, where they were trained to promote social sense, high tolerance, mutual respect and respect.

\section{REFERENCES}

[1] Ibung, Dian. (2009). Mengembangkan Nilai Moral Pada Anak. Jakarta: PT Elex Media Komputindo.

[2] Ikhsan, Fuad. (2005). Dasar-Dasar Kependidikan. Jakarta: PT Rineka Cipta.

[3] Pasha, Kamal Musthafa. (2002). Pendidikan Kewarganegaraan (Civic Education). Jogjakarta: Cita Karsa Mandiri.

[4] Rosyada, Dede. (2013). Paradikma Pendidikan Demokratis. Jakarta: kencana prenada media group.

[5] Sukmadinata, Syaodih Nana. (2009). Metode penelitian pendidikan. Bandung: Remaja Rosdakarya. 
[6] Syahputra, Siswandi. (2013). Rezim Media Pergulatan Demokrasi Jurnalisme dan Infotaiment dalam Industri Televisi. Jakarta: Gramedia.

[7] Ubaidillah.A dan abdul rozak. (2014). Pendidikan Kewarganegaraaan, Pancasila, Demokrasi, HAM, Dan Masyarakat Madani. Jakarta: ICCE UIN Syarif Hidayatullah.

[8] Wiharyanto, Kardiyat. (2014). Pendidikan Kewarganegaraan. Yogyakarta: Universitas sanata darma.

[9] Zuriah, Nurul. (2011). Pendidikan Moral dan Budi Pekerti Dalam Perspektif Perubahan. Jakarta: PT bumi aksara. 